stellar motions, the title of this contribution being "A Preliminary Discussion of the Galactic Motions of the Bright Stars of Type I., with Some Additional Material." Mr. C. V. L. Charlier, in the Meddelanden frän Lunds Astronomiska Observatorium, series ii., No. 9, publishes the second of his studies in stellar statistics, entitled "The Motion of the Stars," giving an account of an extensive research into the proper motions of Boss's catalogue based on correlation methods.

Recent Observations of Nove.-The results of a valuable piece of work are recorded by Prof. E. E. Barnard in Astronomische. Nachrichten, No. 4655 . They relate to the present appearance of many of the novæe. which have been discovered from time to time. The following is a very brief digest of some of the notes he gives, but reference should be made to the original paper for further details of each star :-

\begin{tabular}{|c|c|c|c|c|c|c|}
\hline Nova & Discovered & $\begin{array}{l}\text { Max. } \\
\text { recorde } \\
\text { mag. }\end{array}$ & & $\begin{array}{l}\text { Present } \\
\text { mag. }\end{array}$ & & Remarks \\
\hline T Coronze & ... I 866 . & ... 2 & $\cdots$ & 9 & $\ldots$ & Colourless \\
\hline Cygni $\ldots$ & ... 1876. & ... $3-4$ & $\cdots$ & $15^{\circ} \mathrm{O}$ & ... & Hazy \\
\hline Andromedre & $\ldots 1885$. & ... 6 & $\ldots I$ & Invisibl & e... & -- \\
\hline Aurigie ... & $\ldots$ I89I. & $\cdots 4: 5$ & $\ldots$ & I 4 & $\cdots$ & Ill-defined \\
\hline Sagittarii & $\ldots$ I 898. & ... $4 \cdot 7$ & $\cdots$ & 15 & $\cdots$ & Hazy and ill-defined \\
\hline Persei $\quad .$. & $\ldots$ I90I & $\ldots<1 \cdot O$ & $\cdots$ & 12.05 & ... & Colourless \\
\hline Geminorum & (I) 1903 . & $\ldots 8 \cdot 16$ & $5 . .$. & $16 \cdot 3$ & $\cdots$ & - \\
\hline Aquilæ ... & $\ldots 1905$. & .. 5 & $\ldots$ & $<\mathrm{I} 7$ & $\ldots$ & - \\
\hline Lacertæ... & $\ldots 1910$ & $\cdots 5^{\circ} \mathrm{O}$ & $\cdots$ & $12 \cdot 5$ & $\cdots$ & Nebula bluish-white \\
\hline Geminorum & (2) I9I 2 & $\cdots 4$ & & $\begin{array}{l}8 \pm \\
\text { ctuati }\end{array}$ & $\cdots$ & - \\
\hline
\end{tabular}

With regard to the last nova, Prof. Barnard writes: "On February 8, I913, with good seeing and at the proper focus the $\mathrm{Ha}$ image of Nova Geminorum No. 2 was clearly scen. It was small and sharp and intensely crimson, and was surrounded by a greenishblue halo some $3^{\prime \prime}-4^{\prime \prime}$ in diameter. The normal focus, however, was not different from that of an ordinary star."

\section{THE NATIONAL PHYSICAL LABORATORY DURING 19I2.}

THE annual report of the National Physical Laboratory, Teddington, was presented to the meeting of the general board on April 25, and marks another milestone of stcady progress. The birth of the laboratory but some ten years ago is fresh in the minds of most of us, but many may not realise the extent of its development; few institutions can indeed parallel it in rapidity of growth.

As a nation we were late in starting a national laboratory, but we have been unusually quick in making use of the facilities and advantages which it affords. To it from all parts of the Empire come requests for advice and assistance-requests increasingly exacting and ever-widening in scope; the National Physical Laboratory is fast taking its place as the Imperial laboratory. Its staft, formerly fewer than half a dozen, now numbers 150 of all grades; its history recounts an uninterrupted succession of new buildings. Progress such as this bears witness to the labour and devotion which the director, Dr. Glazebrook, has showered on the laboratory, to the loyal cooperation of his staff, and to the wise administration of the Royal Society.

The National Physical Laboratory is steadily gaining in the nation's appreciation; in common fairness the nation should put itself in the position of being able to say that it has provided for the laboratory in such fashion that financial cares need not distract its administrators from their proper sphere. The NO. 2276 , VOL. 9I] laboratory should be able to attract and keep on its staff brilliant young men who are keen to work at research for the profit of the nation and the advancement of learning. The men are not wanting; it is for the country to see that their remuneration is commensurate, and that they are adequately housed and equipped for their work.

The laboratory is being increasingly consulted by the different Government Departments. During the year various matters have been carried out for the Admiralty, the War Office, the Foreign Office, the Home Office, the Board of 'Trade, the Local Government Board, the India Office, \&c. Last year the expenditure amounted to more than 32,oool.; the 'Treasury grant was only joool. The remaining $25,000 l$. had to be raised by payments for work done and by donations.

A new building designed to accommodate the administration offices and the optics division is approaching completion; this will satisfy a most imperative need. Generous donors have supplemented the special Treasury grant of $\mathrm{I}_{5}, \mathrm{oool}$. for the purpose; these include the 1851 Commissioners $(5000 l$.) and a number of the City Companies. But further funds for equipping these and other departments are urgently needed. The new buildings are to be opened by the Right Hon. A. J. Balfour on the day of the annual visitation, Thursday, June 26 .

Turning now to the rorls of the year, its comprehensive nature is at once evident. The National Physical Laboratory is a physical laboratory in the widest sense, and accordingly we find in its yearly record papers on almost every branch of physics and technology. Some forty original communications were published during the year; it is possible now to touch on only a few of these.

Taking first the work on the fundamental electric units, the Lorenz apparatus for the determination of the ohm in absolute measure was completed during the early part of the year, and a large number of experiments have already been carried out by $\mathrm{Mr}$. F. E. Smith. Some idea of the precision attained may be gathered from the fact that the estimated probable error of any single measurement is of the order of two parts in 100,000 . The final result of the measurements is not yet available, but it may perhaps be said that the value will probably be somewhat less than has been generally supposed. Comparisons with the resistance-standards of the Bureau of Standards, the Reichsansalt, and the Laboratoire Central d'Electricité have been made during the year, with the result that the English and German values were found to agree within one part in a million; the American value was ten parts in a million greater.

Mr. Campbell has evaluated the ohm in absolute units by two alternating-current methods, remarkable for their ingenuity. The testing of wavemeters is becoming an important feature of the work in the electrical department.

The British Radium Standard, consisting of 2 I millisrammes of extremely pure radium-chloride, is now deposited at the laboratory. Dr. G. T. Beilby provided the funds for the purchase of the standard, which has been compared with the international standard at Sèvres, and will shortly be available for standardising radium preparations.

An important paper dealing with the discharge of electricity from carbon at high temperatures was presented to the Royal Society by Dr. Harker and Dr. Kave. By reason of the conditions and magnitude of the experiments, ionisation currents amounting to several amperes were obtained.

The thermometry division is investigating the thermal conductivities of the various heat insulators used 
for cold-storage purposes, and for steam-pipe lagging -a piece of worls which presents special difficulties and has long been needed. The equipment for testing the thermometers hitherto verified comparisons of candle-power units have been made with the Bureau of Standards and the Reichsanstalt through the medium of tungsten filament lamps ( $\mathrm{Mr}$. Paterson). Tho agreement of the results is extremely

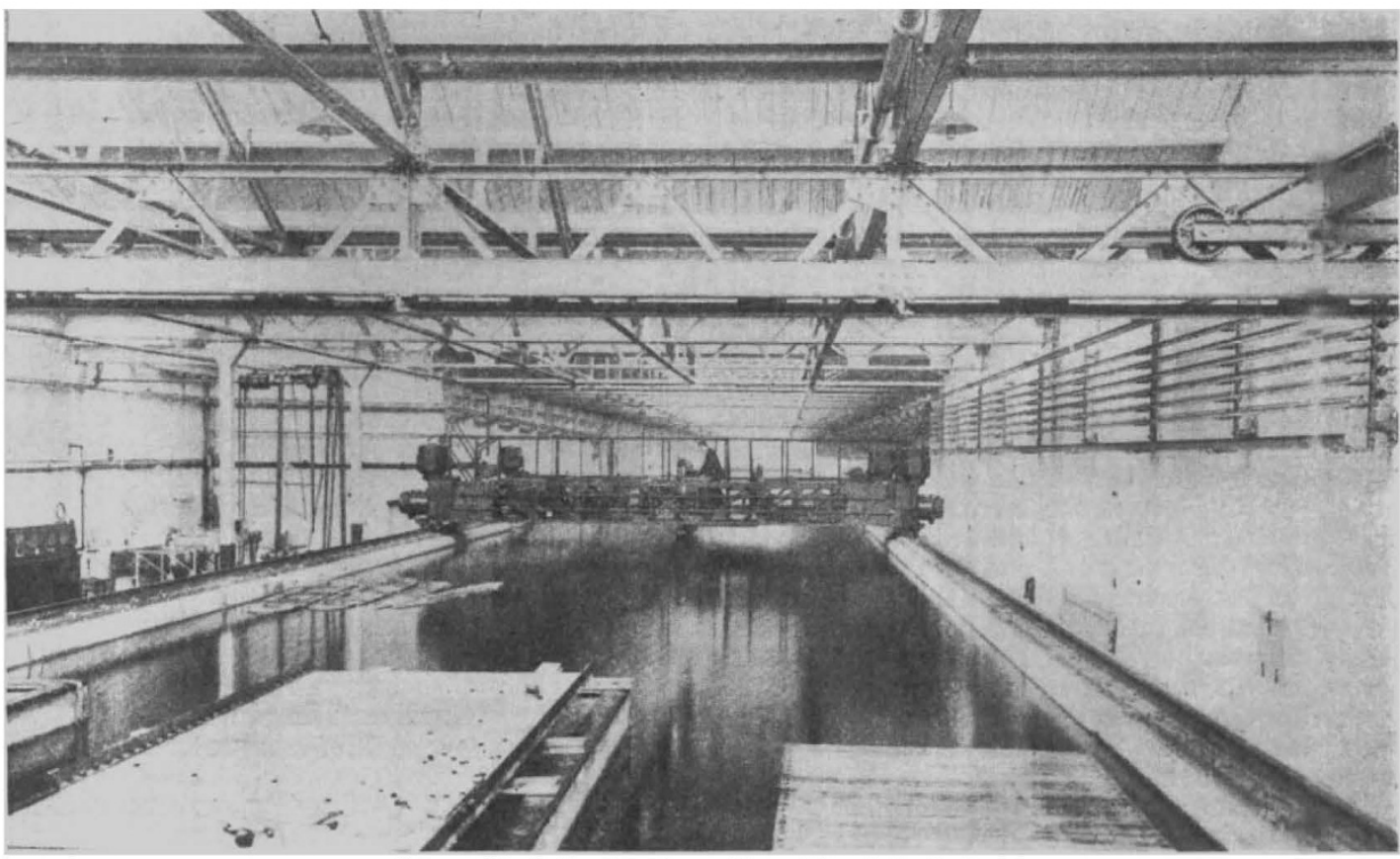

FIG. x. - The tank and carriage, with motel ready for towing

at Kew Observatory has been set up; some idea of the magnitude of this worls will be gathered from the fact that more than 33,00o thermometers were tested last vear. A research on the riscosity of nils has been completed by Mr. Higgins. good, and incidentally affords evidence that the photometry of lights of different colours is not of necessity liable to the errors which are commonly attributed to it. Work has been published by the electrotechnics livision on the clectric strength of ebonite, the com-

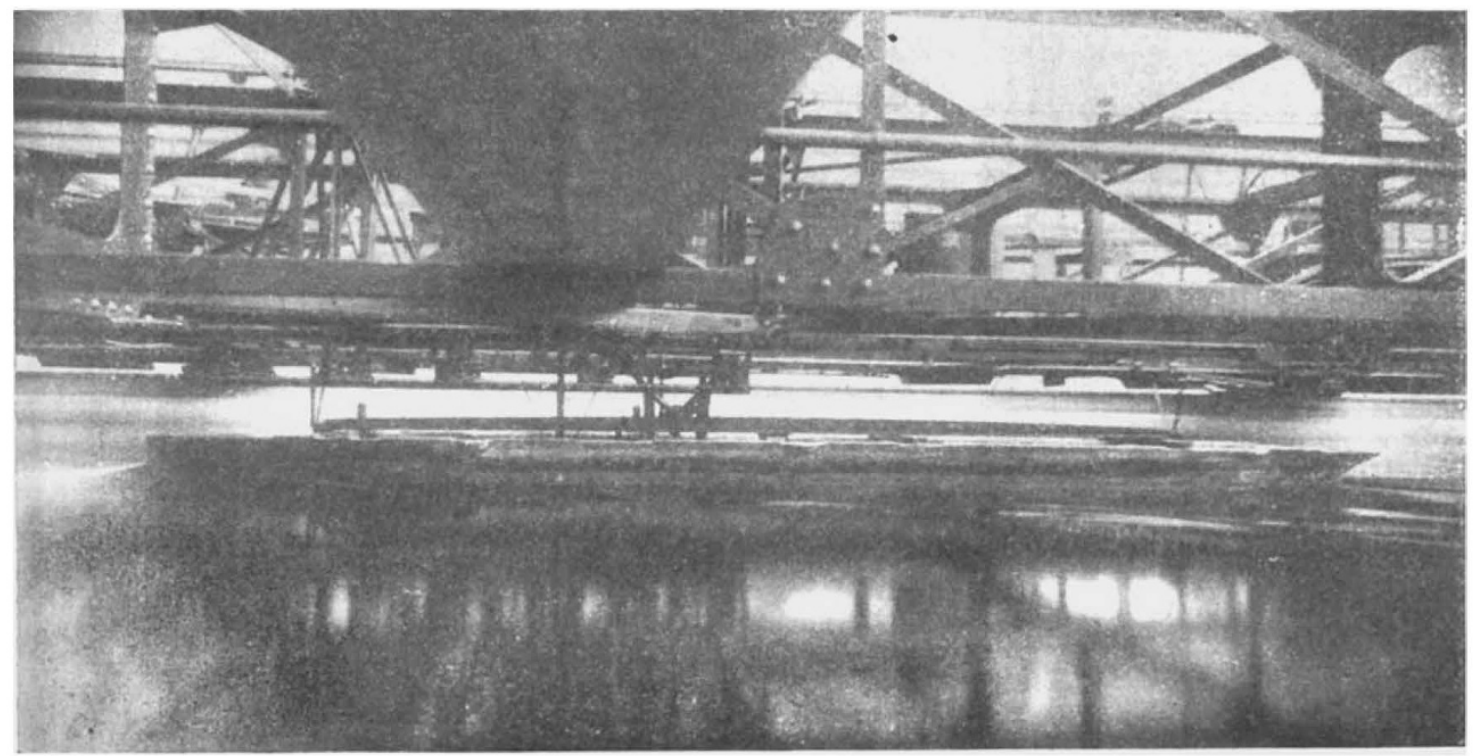

FIG. 2,-Model being towed-showing waves created.

The photometric division has conducted an inquiry into the visibility of ships' lights, and is at present engaged in an investigation of "glare," particularly that produced by motor-car headlights. InterNO. 2276 , VOL. 9I] pressibility of micanite, the dielectric losses in insulators (Mr. Rayner), and the heating of flexible cords and cables (Mr. Melsom).

Some important researches have been carried out 
by Mr. Baker and his colleagues in the Naval Tank. The most noteworthy is that with a series of ship models, each having the same principal dimensions, but with a different distribution of the displacement in a longitudinal direction. The experiments revealed the limits of speed to which various forms can be driven without excessive wave-making, and have also increased the general knowledge of eddy-making at the sterns of ships. An extensive series of experiments has also been carried out on hydro-aëroplane floats. Fig. I gives a general view of the tank with a model in place under the carriage by means of which the model is towed. Fig. 2 shows the wave profiles for a model of mercantile form with fairly bluff ends. It is satisfactory to note how very small the loss of water from the tank still continues-a tribute to its design and construction.

In the metallurgical department, Dr. Rosenhain and $\mathrm{Mr}$. Archbutt have published the tenth report of the alloys research committee of the Institution of Mechanical Engineers. The report, which deals with the alloys of zinc and aluminium, contains features of great interest in view of the increasing importance of light alloys in aëronautical and instrument work. Dr. Rosenhain and Mr. Ewen have communicated an important paper on intercrystalline cohesion in metals, while Mr. Humfrey has been working on the effects of strain in iron at high temperatures.

The metrology division has been largely occupied with the arrangements for the reception of the Kew Observatory test work. The behaviour of the silica standard metre has been closely followed, and the value of its expansion-coefficient determined (Mr. Donaldson).

Dr. Stanton and his staff have carried out extremely valuable work in a number of directions, more particularly on wind-pressures (at the Tower Bridge), on the frictional high-speed flow of water and air in pipes, and on the pressure and flow round aëroplane surfaces. The experiments conducted in the 4 - $\mathrm{ft}$. wind channel have afforded valuable information to the Royal Aircraft Factory at Farnborough in designing biplanes and dirigible balloons. The Treasury has accordingly authorised the erection of a new $7-\mathrm{ft}$. channel at the laboratory; this is now approaching completion.

The new experimental road constructed for the Road Board is complete, and abrasion and endurance tests have been begun.

The optical division has been concerned with the testing of photographic shutters, the absorbability of glass for ultra-violet light, and the testing of telescope objectives and trial lenses. The staff took an active part in the organisation and proceedings of the Optical Convention which was held during the year at South Kensington.

This short summary may suffice to give a notion of some of the many fields of activity in which the National Physical Laboratory is working for progress. There are important problems waiting to be talzen up; it is in many cases purely a question of "ways and means" which prevents a start being made.

\section{THE ROYAI OBSERVATORY,} GREENWICH.

$\Delta \mathrm{T}$ the annual visitation of the Roval Observatory on June 7 , the Astronomer Royal, Dr. F. W. Dyson, F.R.S., presented his annual report. The following extracts indicate the chief items of interest:-

The observatory has ceased to generate its own electric current for lighting and other purposes, and now obtains current from outside. Alternating instead of direct current is now used, and a small supply NO. 2276 , VOL. 9I] of direct current is obtained by means of a rotary converter.

In the new magnetic observatory, shortly to be erected, provision is made for the continuation of the long series of Greenwich observations of the variations of the magnetic elements. This series is unique as regards the length of time during which observations have been made on the same site. The care which has been taken to guard the observatory from all artificial electromagnetic disturbances which could affect the accuracy of the observations has preserved the suitability of the site for such work.

Observations of double stars have been made with the 28-in. refractor from a working catalogue containing all known double stars showing appreciable relative motion, and a number of pairs from the catalogues of Hussey and Aitken under 2" separation.

$\kappa$ Pegasi was observed on five nights, $\delta$ Equulei on three nights, 7o Ophiuchi on thirteen nights, and $\epsilon$ Hydræ on one night.

The 26-in. refractor, the 30 -in. reffector, and the 6-in. Cooke triplet have been in constant use during the year. The new cell for the crown lens was received and mounted in July. The adjustment of the crown and flint lenses for tilt and eccentricity relative to one another was made in August.

During the year I64 plates were taken for determination of stellar parallax, I24 of these being new plates and forty being re-exposures of plates taken six months previously. The programme for each star consists of six photographs. Three photographs taken in the evenings are re-exposed in the mornings about six months later, and are then developed. Three plates are exposed in the mornings, and, after reexposure six months later, are also developed. For several stars the cycle has been completed and the plates have been measured for three stars: The results obtained are $+0.082^{\prime \prime} \pm 0.017^{\prime \prime},+0.043^{\prime \prime} \pm 0.009^{\prime \prime}$, and $0.014^{\prime \prime} \pm 0.0 \mathrm{r} 2^{\prime \prime}$. The star which gave a negative parallax is one with a small proper motion. It is considered that these probable errors are too large, and that one of $\pm 0.005^{\prime \prime}$ should be attainable. The increased constancy in the adjustment of the object glass secured by the new cell, and the use of the rotating sector by which the star observed is reduced to the magnitude $10.5 \mathrm{~m}$. to II.om. of the comparison stars, are expected to make a considerable improvement.

The 6-in. Cooke triplet which belonged to the late Mr. Franklin Adams has been employed in the determination of the photographic magnitudes of the stars brighter than 9.0m. in the Greenwich astrographic zone. During the year fifty-three photographs of fields compared with the standard polar area have been taken. Fifty-six plates have been measured, completing the eighty-eight necessary for the whole zone. The catalogue of the resulting magnitudes is nearly completed, and will contain 8000 stars.

Fifty-nine photographs of Neptune and satellite, taken in rgog-Io, have been measured, and the results published.

At the date of the last report, $\mathrm{r}_{52}$ out of the 206 Franklin-Adams photographs had been counted in the manner then explained. During the year fifty of the remaining plates have been dealt with. The four plates still uncounted have not yet been reccived from Johannesburg.

The requisite photometric data for the reduction of these counts to statistics based on actual photographic magnitudes are now being obtained at a steady rate. The plan of taking long exposures on a field and a standard polar area has been abandoned, because of the rarity of nights on which the sky is uniform and constant for more than one hour. Instead of this, exposures of $5 \mathrm{~m}$. duration are being taken on the 